\title{
The Legacy of Landlords: Educational Distribution and Development in a Comparative Perspective
}

\author{
Tim Wegenast
}

\begin{abstract}
This paper shows that differences in educational outcomes within and between Asia and Latin America are caused in part by the type of agricultural production system. It is argued that, in contrast to states organized around family farming, countries exhibiting plantation style agriculture tend to neglect broadly based educational policies. Plantation owners may have cur tailed educational expansion to impede political mobilization of rural workers in order to secure a cheap supply of hired labour and monopolize the political arena. Results of panel data analysis as well as OLS cross sectional regressions show that the export of crops grown on large landhold ings substantially decreases secondary education attainment levels and governments' investments in secondary schooling. Simultaneously, these same exports are associated with higher tertiary education levels. The quantitative analysis is complemented by historical evidence of agrarian elites attempting to hinder the development of mass schooling in many countries.
\end{abstract}

Keywords: Education $\cdot$ Plantation economies $\cdot$ Agrarian elites $\cdot$ Inequality

\section{Das Vermächtnis der Plantagenwirtschaft: Bildungsungleichheiten und Entwicklung in einer vergleichenden Perspektive}

Zusammenfassung: Der vorliegende Beitrag zeigt, dass Bildungsunterschiede zwischen und innerhalb Asien und Lateinamerikas zum Teil auf unterschiedliche landwirtschaftliche Produk tionssysteme zurückzuführen sind. Im Gegensatz zu Ländern, deren Agrarproduktion hauptsäch lich auf landwirtschaftlichen Kleinbetrieben beruht, tendieren Plantagenwirtschaften dazu, eine umfassende Bildung ihrer Bevölkerung zu vernachlässigen. Großgrundbesitzer haben sich gegen eine breite Bildungsexpansion gewehrt, um die politische Mobilisierung von Agrararbeitern zu verhindern und somit die Bereitstellung billiger Arbeitskräfte und das Monopol über den poli tischen Entscheidungsfindungsprozess sicher zu stellen. Ergebnisse einer gepoolten Zeitreihen und Querschnittsanalyse deuten darauf hin, dass der Export von Plantagenprodukten sowohl die Sekundarbildungsabschlüsse als auch die Sekundarbildungsausgaben eines Landes verringert. Gleichzeitig wird diese Exportkategorie mit mehr Hochschulausbildung in Verbindung gebracht.

Comments from Carles Boix, Francisco Ferreira, Gøsta Esping Andersen, Jacint Jordana, Lakshmi Iyer, Ricardo Hausmann, Stanley Engerman, Sunnee Billingsley as well as two anonymous reviewers are gratefully acknowledged. I also want to thank the Catalan Government for providing generous funding.

Dr. T. Wegenast $(\Delta \Delta)$

German Institute of Global and Area Studies (GIGA), Neuer Jungfernstieg 21, 20354 Hamburg, Germany

e mail: wegenast@giga hamburg.de 
Die quantitative Analyse wird um historische Evidenz für den Widerstand der Agrareliten gegen die Entwicklung einer umfangreichen Schulausbildung ergänzt.

Schlüisselwörter: Bildung $\cdot$ Plantagenwirtschaft $\cdot$ Agrareliten · Ungleichheit

\section{Introduction}

The question of why East Asia overtook Latin America has been widely addressed by the development debate. When contrasting Latin America's relatively poor economic performance with Asia's positive growth record, scholars relied on a particular set of political choices such as certain industrial, trade or macroeconomic policies. Surprisingly, the majority of existent studies tend to analyze structural phenomena in a rather static and ahistorical way. Hence, traditional analytical frameworks have paid scant attention to the role of agrarian class relations and its possible impact on educational outputs when explaining the different development paths adopted by both regions.

A comparison between educational attainment figures of Latin America and East Asia shows two different pictures. While most educational policies within Asia have been broadly-targeted in the last three decades, Latin American governments particularly emphasized primary and higher education at the expense of secondary schooling. Why the Asian population enjoyed so much more secondary schooling, while Latin American states seem to have prioritized tertiary education, has not been systematically addressed.

Departing from the core argument that agrarian elites influenced public policies to secure their fundamental interests, the present paper seeks to explain distributional conflicts over educational levels in Latin America and Asia by looking at patterns of agricultural production. The main claim is that a powerful class of large Latin American landowners may have contributed to the development of educational inequalities; these highly resilient elites used educational policies to secure cheap, coerced labour and preserve the political status quo, ensuring continued high profits. Thus, I sustain that agriculture shaped countries' development process by having long-lasting effects on their educational policies.

It is claimed that different landownership structures in Latin America and Asia have translated into distinct political power constellations. Latin America's high land concentration and its specialization on primary as well as processed-primary goods grown on large plantations such as sugar, banana or coffee gave rise to a politically influential rural elite that dominated the political decision making process until very recently. Extracting its revenues out of a very narrow and immobile economic activity, this elite opposed the promotion of secondary education in order to guarantee a cheap labour force for their labour-intensive plantations. Moreover, by blocking the expansion of secondary education, landlords minimized workers' political articulation and mobilization capacity and retained the monopoly over the political arena. This strategy was reinforced by suffrage laws based on literacy criteria. At the same time, the landed elite advocated public investment in universities, ensuring higher education for their children and satisfying their demand for a certain amount of more sophisticated technical skills.

Asian land distribution, in contrast, has been more equal throughout history, as smaller family-owned farms produced crops such as rice or certain types of vegetable. Political 
power was never concentrated in the hands of a few influential landowners, giving Asian governments a much broader base of political support. Small farmers, a rather fragmented and politically inarticulate agrarian class, shared their political power with upcoming urban interest groups.

Regression analysis employing generalized estimation equation on time-series crosssectional data as well as simple cross-sectional OLS estimators are used to assess empirical evidence for the paper's main claim. The export of crops grown on large plantations as a share of total exports is taken to proxy economic and political power of large landowners as well as their dependence on cheap labour. The statistical analysis is complemented by historical evidence drawn from several developing countries.

The paper proceeds as follows: the next section briefly reviews relevant literature, outlining the intended contribution of the article. Section three reveals the differences in educational attainment figures between Asia and Latin America as well as their different agricultural export patterns. The following part explains the emergence of diverging agricultural production systems as well as its consequences on levels of landlords' political power. Section four elaborates how landlords influenced educational policies to keep rural labour cheap and maintain their control over the political decision making process. Historical evidence of big landlords' resistance towards educational reforms in several Latin American and Asian countries is presented in section five. The econometric analysis is shown subsequently. The last section summarizes the main findings and points to areas for further research.

\section{Literature review and empirical contribution}

Barrington Moore was among the first scholars to consider agrarian class relations as a predictor of political transformation processes. Studying regime transitions, Moore (1966) explained European democratic breakdowns with the existence of large landholdings and the survival of a powerful class of landowners into the period of modernization. The author pointed out that these landlords took advantage of labour-repressive agriculture throughout history, using political coercion to secure themselves cheap labour.

More recently, other authors focused on the influence of special interest groups like large landowners to study political decisions and socio-economic phenomena. Acemoglu and Robinson (2000, 2006a), for example, develop the idea that groups whose political power is threatened will block technological advances. With their insightful formal model, they explain how resilient landowning elites captured political and economic institutions and promoted labour-repressive policies in agriculture until recently (see Acemoglu and Robinson 2006b). Boix (2003) stresses the role of asset specificity when analysing institutional change. In his model, owners of fixed assets such as land or oil oppose any attempt of democratisation, as this could lead to the expropriation of their assets (see also Bueno de Mesquita and Smith 2009).

Similarly, Engerman and Sokollof $(1997,2005$ a) made an important contribution by assuming the persistence of institutions and linking initial factor endowments with different paths of development within the Americas. According to the authors, South American states began with extreme inequality by cultivating crops that are grown on large plantations. This initial inequality was perpetuated in the institutional structures, allowing 
the rural elite to extract great personal fortunes and consolidate power. In contrast, North America specialised in small-holder agricultural production, facilitating the emergence of more equitable institutions. Thus, initial factor endowments may explain the divergent long-run economic performance in North and South America. Acemoglu et al. (2001) also revert to geographic conditions when assessing the formation of institutions. In their seminal work, the authors show that extraction-oriented regimes emerged in regions where European colonisers could not settle due to high mortality rates caused by a large disease burden. In these so called "extractive states", no institutional arrangements promoting e.g. the protection of private property were introduced. Instead, the colonisers installed very resilient repressive institutions in order to exploit a cheap labour force and "transfer as much of the resources of the colony to the colonizers" (Acemoglu et al. 2001, p. 1370). Consequently, investment in human capital was low.

Studies on the relationship between patterns of landownership, political power of the landowning class and educational inequalities are rare. Bowles (1978) was among the first to theoretically contemplate how the landlord class and capitalists try to influence educational policies in order to distort the distribution of economic rewards in their favour and reproduce the prevailing exploitative class relations. In Bowles' considerations, both dominant classes disagree on the optimal amount of educational provision; capitalists are interested in achieving high levels of labour productivity but, simultaneously, want to avoid militant political activity among workers. In contrast, landlords have little economic interest in expanding education. Through formal modelling, Bourguignon and Verdier (2000) describe this dilemma faced by the urban oligarchy when deciding whether to subsidize education of the poor. Following similar reasoning, Galor et al. (2006) construct an explicit economic model that focuses on the conflict between the landed aristocratic class and the capitalist elite during the transition from agriculture to an industrial economy. While capitalists strive for a better educated workforce, landowners' interests lay in constricting potential mobility of the rural labour force by blocking the promotion of schooling.

Although these models propose very interesting testable implications, they do not actually assess the empirical impact of landlords' power on the distribution of education. To the best of my knowledge, hardly any study has analyzed how the political influence of the agrarian sector may have affected the composition of educational policies in a comparative way. Lindert (2004a, 2004b) analyzes various factors explaining student enrolment in primary school between 1881 and 1937. By using the share of men who voted as proxy for landed interest power, the author employs cross-sectional regression analysis and concludes that much of the blame for delaying the expansion of primary education resided in powerful landed elites "opposed to schooling the masses at tax payer expenses" (Lindert 2004b, p. 33). Although undoubtedly very insightful, the study employs a very crude indicator of landlords' political power that is of debatable validity.

Assessing the relationship between land distribution and economic development, Erickson and Vollrath (2004) conclude that lower land inequality across the agricultural population is associated with greater public provision of education. However, the authors' landholding Gini coefficients rest upon a very limited number of observations (Vollrath 2004, p. 7) and the surveys on which the observations are based are partly inconsistent (see Frankema 2006, p. 7-8). Finally, two case studies suggest there might be a causal connection between landownership and education. Analyzing colonial land revenue institutions in India, Banerjee 
and Iyer (2005) find that areas in which property rights were historically given to landlords received significantly lower investments in health and education. Galor et al. (2006) find a negative effect of land inequality on education expenditure using cross-sectional data on the United States from the beginning of the $20^{\text {th }}$ century.

The paper contributes to this existing literature in different ways. Overall, it builds upon previous studies that used agrarian class relations to understand countries' social, economic and political development by linking agriculture to the provision of education. As such, it probes more deeply into landlords' possible motivations for blocking the expansion of broadly-targeted educational policies. Moreover, it differentiates between various educational categories and uses export specialization figures instead of the widely criticized land Ginis to proxy for landlords' power. Also, the theoretical approach is novel by relying explicitly on elites' self interest to explain educational differences between Asia and Latin America. A final contribution of the paper is the focus on other natural resources such as minerals or fuels as potential determinants of human capital formation.

\section{Educational attainment and countries' export composition}

As mentioned above, major differences in the development of educational attainment figures can be observed for Asia and Latin America and the Caribbean. Figures 1 and 2 plot the mean value of the different educational categories over the period 1960-2000 for both continents. The educational categories are measured by the percentage of the total population over 15 years of age having completed primary, secondary or higher education (or no schooling). Data comes from Barro and Lee (2001).

The plots show, among other things, that Asian countries seem to have prioritized secondary education much more than their Latin American counterparts. In Latin America and the Caribbean, primary education attainment levels remained almost unchanged at a rather high level throughout the whole period, while higher education attainment levels increased. The gap between secondary and higher education is substantially narrower than in Asia. Compared to Asia, this region seems to have neglected secondary schooling; in Hong Kong, South Korea and Sri Lanka, almost $60 \%$ of the population enjoyed secondary schooling by the year 2000. Concomitantly, the percentage of people having attained primary education drops as the Asian population increasingly enjoys secondary schooling. ${ }^{1}$

Nevertheless, one can find strong variation of educational figures within Latin America. While many countries exhibited secondary attainment rates of bellow $20 \%$ throughout the analyzed period, some others resemble the Asian experience to a certain extent (see Figs. 3 and 4 below). None of the states, however, showed attainment figures higher than $40 \%$. Section five will elaborate on this point, demonstrating that these two groups of Latin American countries also have distinct agrarian structures and a class of landlords with different political power.

1 Note that the data reflects the percentage of the population having completed primary or secondary education but nothing higher. Thus, the categories are exclusive. 
Fig. 1: Educational attainment in Latin America

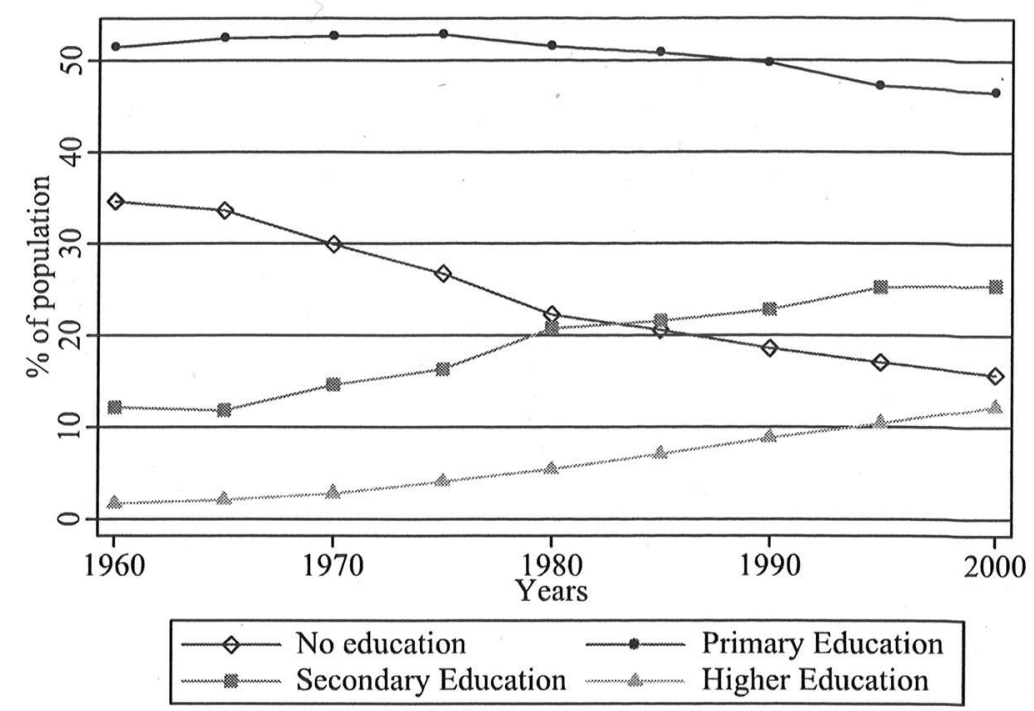

In order to relate differences in educational attainment to diverging agrarian structures, one has to argue that educational outcomes show a certain degree of path-dependency and have been rather resilient from the turn of the century until modern times. Indeed, historical data compiled by Nuñez (2005) lead to the conclusion that educational figures hardly changed within most of Latin America between 1900 and 1950. The author points out that countries with low literacy and primary enrolment rates in 1900 continue to be illiterate in 1950. In contrast, those countries with relatively high literacy rates by the beginning of the century, like Argentina, Costa Rica, Jamaica or Uruguay, continued educating their citizens. $^{2}$

Differences between both regions are not limited to the composition of these four educational categories. Latin America and Asia also present quite distinct trade specialization patterns. ${ }^{3}$ Figures 5 and 6 plot world trade data from the Statistics Canada World Trade Database ${ }^{4}$ recently compiled and updated by Feenstra el al. (2005) for the period 1962-2000. ${ }^{5}$ The data is organized by the 4-digit International Standard Trade Classification, revision 2. The total export of a country was divided into aggregates according to a classification by Leamer (1984). In addition, the amount of plantation crop exports was calculated. ${ }^{6}$

2 Data compiled by Engerman et al. (2000) show a very similar picture.

3 Note that this paper refers to the export structure rather than looking at production figures. This choice was primarily a matter of data availability. Production data is only available for a shorter time span and less detailed than export data, and is rather unreliable for some of the reported countries. However, a high correlation between production and export output can be assumed.

4 Statistics Canada revised the United Nations trade data to fit the Canadian trade classification.

5 Data for the year 1962 was used as proxy for the year 1960. The data is available at http://cid. econ.ucdavis.edu/ (January 20 $\left.0^{\text {th }}, 2009\right)$.

6 The category plantation crops (also called "cash crops") represents agricultural labour intensive goods usually gained from cultivation on large plantations: bananas, oranges, orange juice, sugar, coffee, cocoa, tobacco, palm nuts, palm kennels, rubber, palm oil, coconut oil. 
Fig. 2: Educational attainment in Asia

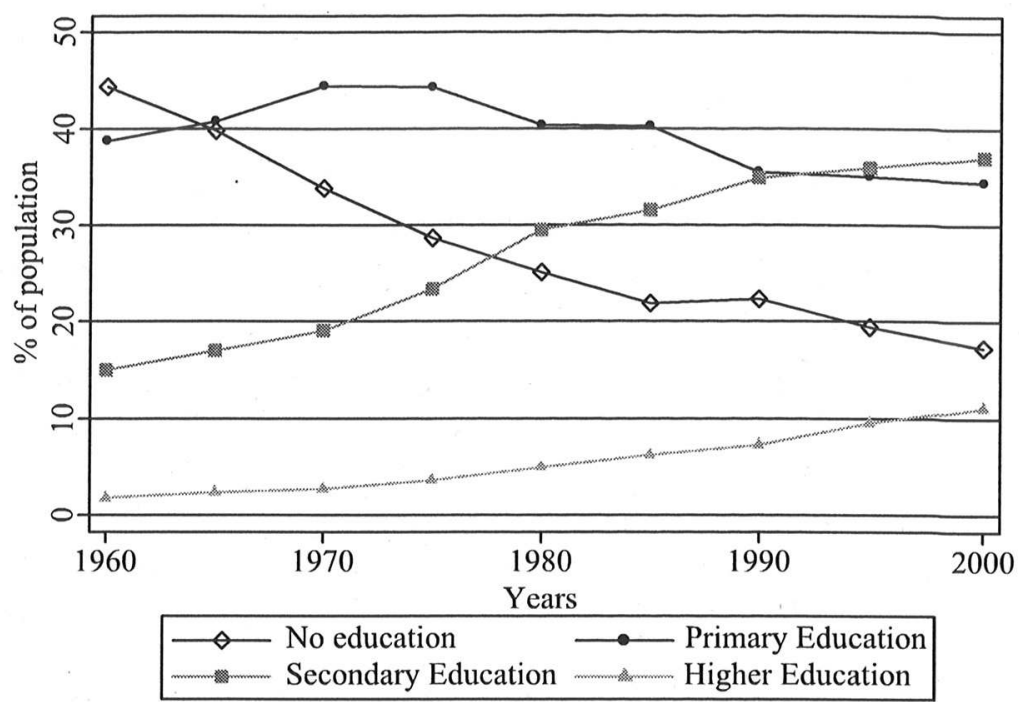

The figures show mean values of the share of labour-intensive and capital-intensive manufacturing as well as plantation crop, forest and cereal exports relative to the regions' total export. While plantation crops were a major source of export revenue in Latin America, they played only a marginal role in Asia. In the 1960s, this category made up more than $50 \%$ of total Latin American exports and, four decades later, it still accounted for almost $14 \%$. In contrast, exports of crops grown on large plantations were irrelevant compared to other agricultural goods such as cereals or forestry in Asia. Excluding the year 1975, exports of plantation crops never reached more than 5\% of total exports. Also, Asian countries specialized in the export of labour-intensive manufacturing such as footwear, furniture or clothing. In Latin America, the export of these kinds of products only became important after 1985.

The export specialization figures shown above reflect the different patterns of landownership structures found in the two regions. While agricultural land was concentrated in the hands of few owners in Latin America, tenant, family or peasant farming remained a basic structural element of Asia's rural economy. The next section illustrates these differences and explains how they relate to the political power of the agricultural sector.

\section{Factor endowments, landownership and landlords' political power}

In Asia's agrarian production, products such as rice or certain types of vegetables and grains are grown on family-owned plots or smaller tenant land. In contrast, crops such as coffee, rubber, bananas or sugar cane seem to require large plantations such as in Latin America and the Caribbean. The cultivation of these different types of crops is reflected in the landownership patterns of both regions. Tatu Vanhanen (1990) calculated the share of family farms over the total area of holdings for the period 1960-1980. Not surprisingly, in the nine South-East Asian countries analyzed, more than $57 \%$ of the total holdings were considered family-owned, while in the 22 Latin American states, only $30 \%$ of total lan- 


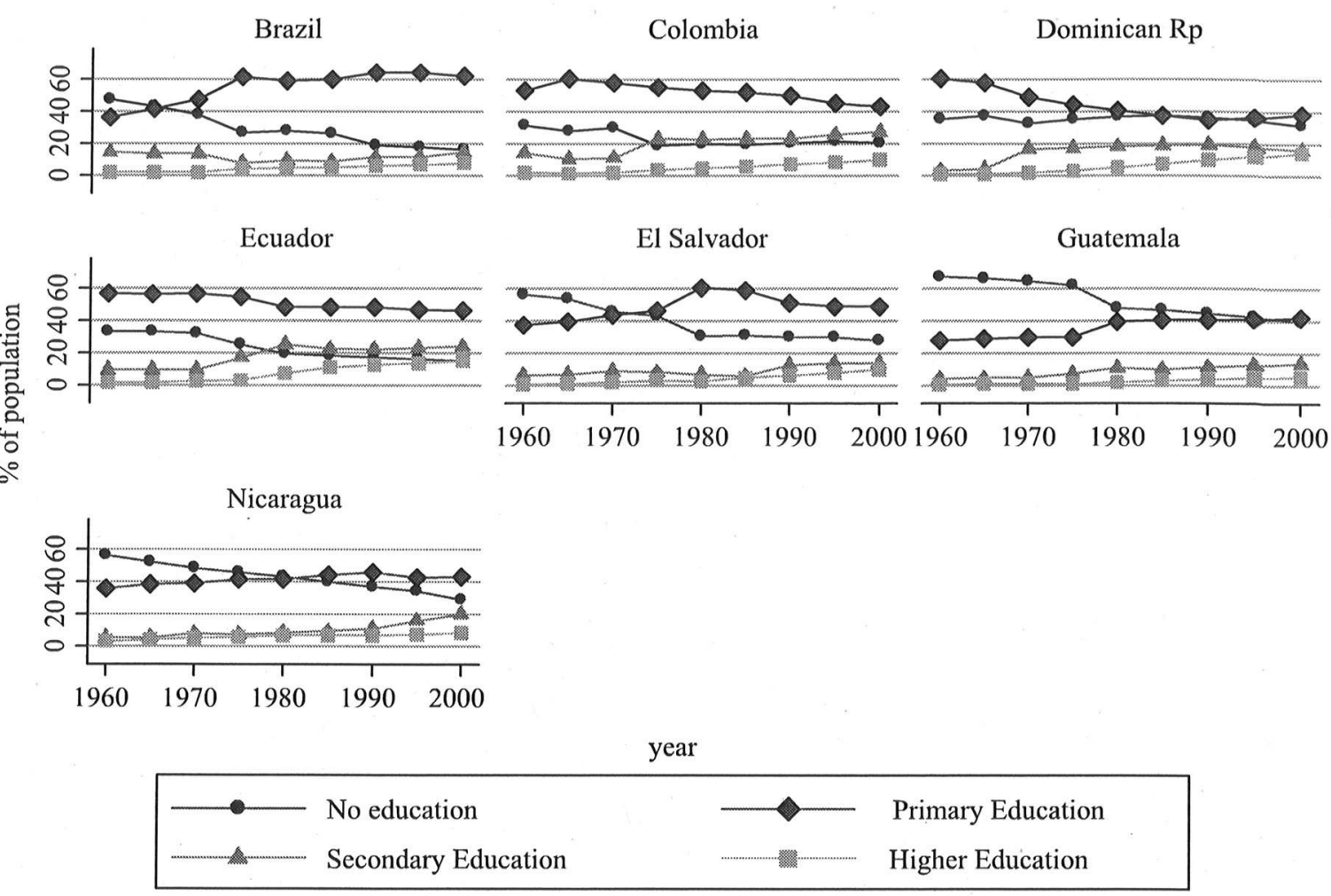

Graphs by country

Fig. 3: Educational attainment under powerful class of big landowners

downership satisfied this criterion. In countries such as Venezuela, Paraguay, Nicaragua or Guyana this number was lower than $18 \%{ }^{7}$

The differing landownership structures can be seen as a product of different factor endowments and, to a certain extent, distinct land reform policies. In general, Latin American countries can be classified as relatively land-abundant, while East Asian states are labour-abundant and land-scarce (Malaysia being the only exception). In the Americas, geographical space was conducive for cultivating crops that, for profitability reasons, have to be planted in larger scale. Coffee, bananas or rubber trees, for example, need plenty of time until they start producing fruits. Because those plants can only be harvested after several years, large plantations ensure economic profitability. Binswanger and Rosenzweig (1984, p. 527) note that these cash crops are grown on plantations either because of economies of scale in processing combined with co-ordination problems between harvesting and processing or because they require long-term cultures of high maintenance intensity. As shown by Hayami and Ruttan (1985), food crops such as wheat or rice, on the contrary, can be efficiently produced on plots of modest or small size. In

7 These figures are confirmed by new land inequality data recently compiled by Frankema (2006). 


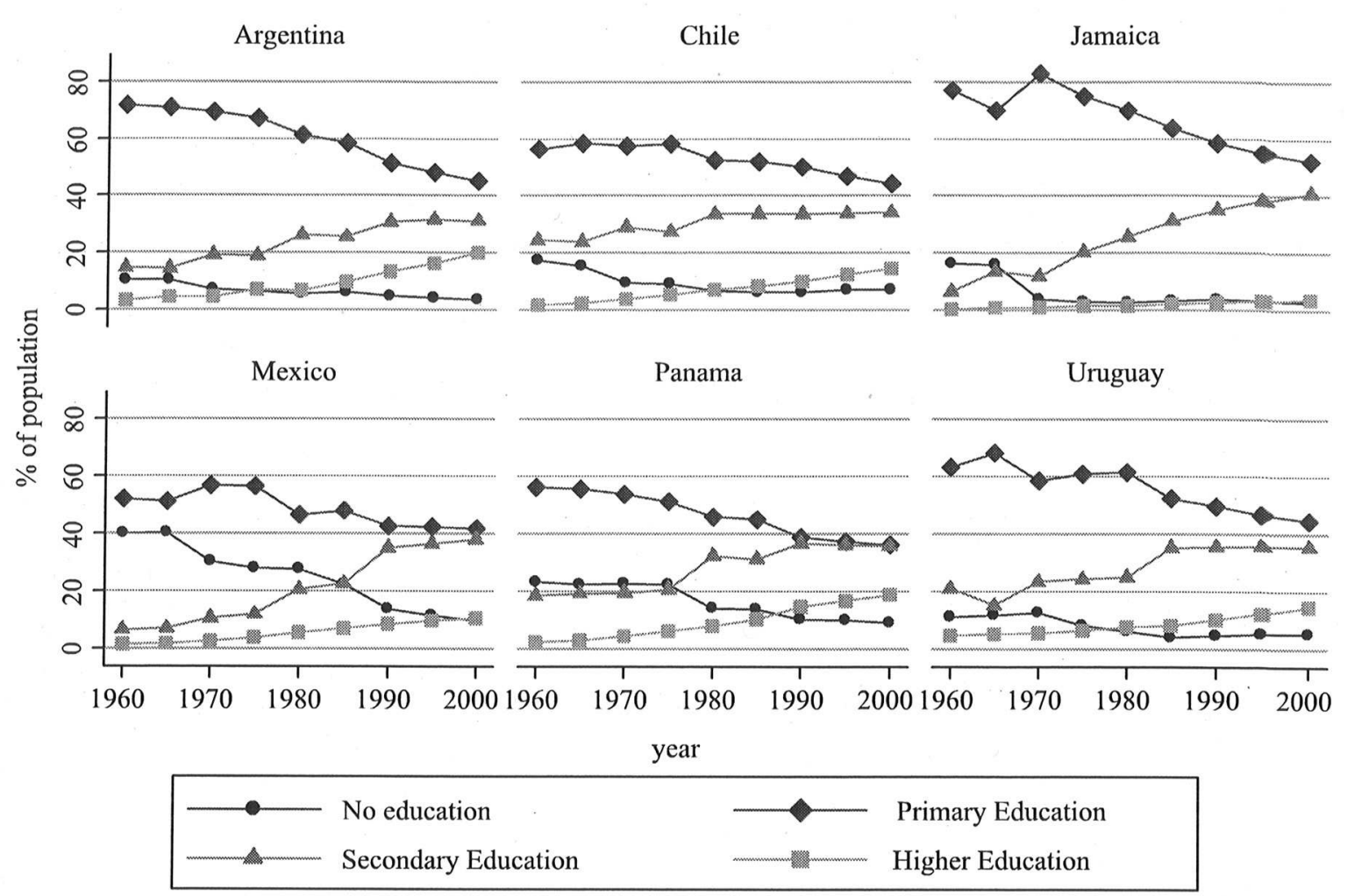

Graphs by country

Fig. 4: Educational attainment under less influential landowning class

fact, Frankema (2006, p. 12) finds some evidence that "land abundant countries are clearly characterized by higher levels of land inequality than densely populated countries". ${ }^{8}$

Thus, plantations of the magnitude of Latin American latifundia (very large landholdings) never developed in Asia as it had much lower land concentration. Handelman (1980, p. 3) notes that, even among those Asian countries with the greatest concentration of land in 1960 - India, Pakistan and the Philippines - none approached the Gini index of Latin American states. Cleary and Eaton (1996, p. 63) acknowledge that even in the case of the Philippines, where "a latifundia system was dominant as a consequence of Spanish colonialism, many held land as small tenant farmers". In contrast, Barraclough (1973, p. 16) notes that by 1960 , the so called latifundia owned about four-fifths of the total land in Latin America.

These differences in the landownership system are important to understand the respective political influence of the agricultural sectors within the two regions. Using Olson's (1965) theory of collective action, it can be argued that the smaller and more numerous

8 Besides diverging factor endowments, one has to look at the timing of land reform when trying to assess the landownership structure of both regions. Following World War II, several Asian countries implemented successful agrarian reforms, due largely to the prodding of the United States or to other external factors such as the North Korean invasion of the South. In countries such as South Korea, Taiwan or Bangladesh, for example, agrarian reform came before signifi cant industrialization had taken place. 
Fig. 5: Latin America's Export Structure

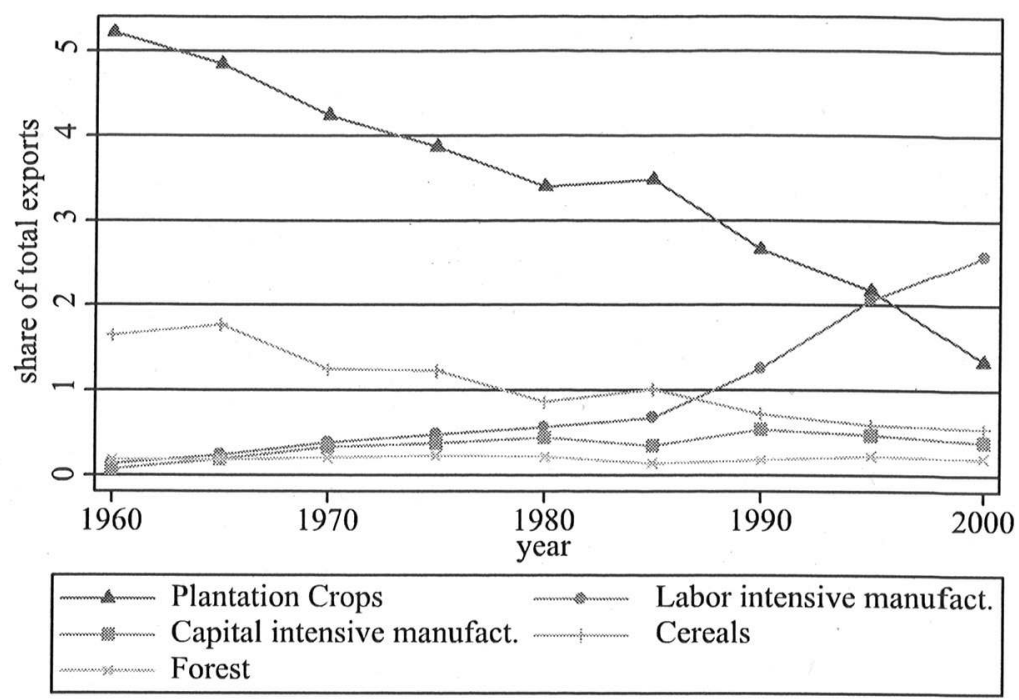

Asian farmers were less able to overcome collective action problems and, therefore, also less capable of imposing their preferences on government policy. This would imply that, because of their large size, Asian agricultural producers were rather unorganized and may have faced competition from other, more organized, special interest groups. In contrast, Latin American landlords, by virtue of their smaller number and their established position, had a comparative advantage in solving collective action problems. ${ }^{9}$

The resilience of the Latin American rural oligarchy is remarkable. ${ }^{10}$ The adaptive and politically influential landlords managed to hold on to power for a very long time, accepting moderate reforms and blocking any fundamental challenge to their dominance (e.g., avoiding redistributive land reforms or the unionization of workers). In countries such as Colombia, Equador or Brazil, powerful gremios (associations of coffee producers, sugar plantation owners, etc.) exercised near veto power over any legislation that threatened fundamental interests of Latin America's landowning elite. Landlords also maintained their economic and political power through the appeasement of the rural population and the "buying" of votes. The hacienda-owning class established "patron-client" relationships with their tenants or hired workers, extending certain benefits or favours (e.g., protection or sponsorship of fies tas) in return for peasant loyalty and votes for a specific political party. ${ }^{11}$

9 The assumption laid down above has already been subject to empirical tests in the literature. Focusing on the characteristics of interest groups themselves, Bates (1981) for example shows that a few large African farmers managed to overcome their collective action problem, receiving input subsidies from governments, in contrast to a mass of small farmers that stayed unorga nized. The author concludes that in the African countries he examined, all special interests (large farmers, urban residents) were satisfied at the expense of unorganized groups (small far mers).

10. Works analyzing landlords' political resilience are Hagopian (1996) for Brazil, Stone (1990) for Central America, Abente (1995) for Paraguay, Hartlyn (1998) for the Dominican Republic or Smith (1979) for Mexico.

11 Works analyzing the importance of clientelist practices in rural as well as urban settings are Cornelius (1977) and Grindle (1977) for Mexico, Schmidt (1977) for Colombia, Stokes (1995) for Peru and Powell (1977) for Venezuela. 
Fig. 6: Asia's Export Structure

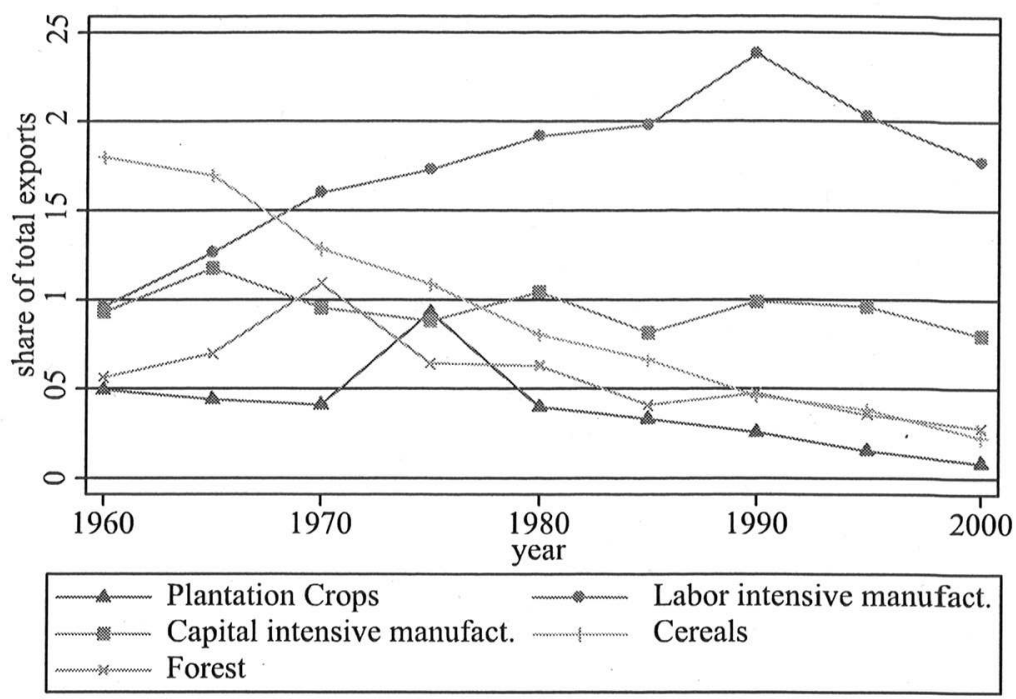

Among other mechanisms through which the landed aristocracy managed to maintain their hegemonic position for such a long time was the blocking of the creation of new parties and the lack of secret voting. Acemoglu and Robinson (2006b, p. 53), for example, describe how the Liberal and Conservative parties in Colombia "reached collusive agreements to make sure that other political parties, especially those representing peasants and workers, were unable to enter the political system." Under the domination of powerful local agrarian oligarchs and the lack of secret voting, agricultural workers were urged to vote for a specific party. Baland and Robinson (2006) show that the introduction of effective secret ballots in Chile led to major changes in voting behaviour, causing electoral losses for right-wing parties representing the landed oligarchy interests in localities dominated by patron-client relationships. ${ }^{12}$ Moreover, the landed elite also shaped institutions to their advantage through suffrage rights based on literacy or wealth requirements (see Engerman and Sokoloff 2005b).

The next section concentrates on another fundamental channel through which agrarian elites fortified their economic revenue base and maintained their dominance over political decisions: the avoidance of broadly-targeted educational policies.

\section{Landlords and human capital}

This paper assumes that landlords have high incentives to influence policy and the variation in levels of political power - a result of different agrarian structures - may predict educational outcomes. ${ }^{13}$ This section develops the proposed causal connection between the level of agrarian power and educational attainment figures within Asia and Latin America shown earlier. As already outlined, landed elite's power is primarily a func-

12 The so called Australian ballot (a system of state provided ballots with provisions to ensure secrecy) was not introduced in Brazil until 1955, 1958 in Chile and 1988 in Colombia.

13 Frieden (1991) argues that sectors like agriculture, in which assets are specific and cannot be easily transferred for other uses, have the most to gain from influencing governments. 
tion of the number and cohesiveness of landlords (conditioned on the landownership structure). The core assumption is that agrarian producers, who extract their revenues out of labour-intensive, plantation-style agriculture, have no interest in the expansion of secondary schooling and may even block government attempts to promote this type of education. Simultaneously, by favouring public subsidies to universities, they guarantee higher education for their children and meet their demand for a certain amount of highly technical skills needed in agriculture.

As cheap labour was vital for ensuring economic profitability in the hacienda-type agricultural system, landlords used all political means to sustain this exploitative agrarian system. Agricultural workers were paid low wages and had poor working conditions. ${ }^{14}$ Huber and Safford (1995, p. 9) note that legal coercion included restrictions on labour mobility and the "legally backed closing off of alternatives to estate labour for the rural population, such as barring access to public land and water and thus subsistence agriculture". As outlined earlier, the dominant landowning class also tried to impede the expansion of political participation and organizational rights for the rural workers. For this purpose, keeping the labour force uneducated was essential.

As known from the socio-political literature, education is conducive to political mobilization and participation. Taking a rational choice approach, Downs (1957) was one of the first to claim that well-educated people demonstrate lower information and transaction costs and, thus, are more likely to engage in politics. Developing a resource model of political participation, Brady et al. (1995, p. 273) confirm this idea by claiming that "citizens who can speak or write well or who are comfortable organizing and taking part in meetings are likely to be more effective when they get involved in politics". They find that more educated citizens are more involved in voluntary organizations and activities, which further one's civic skills and, in turn, increase one's level of political interest and political participation. ${ }^{15}$

Two recent papers analyzed the relationship between education and political mobilization in developing countries. Employing a probability sample of 1484 rural Senegalese citizens, Kuenzi (2006) examines the effect of formal and informal education on political participation. Among other interesting results, the author finds a positive and statistically significant effect of formal education on voting and community participation. Using a data set for 69 village communities in two north Indian States, Krishna (2002) concludes that both more educated and informed people are politically more active.

By impeding the expansion of broad educational policies, big landowners constrained workers' ability to overcome their collective action problem and mobilize for better working conditions and more political empowerment. Also, they maintained the population out of the political arena, as franchise was conditioned upon literacy in many countries for a long time. This idea is well captured by the observation of a landed conservative

14 For a description of working conditions throughout rural Latin America see Duncan and Rout ledge (1977).

15 Political participation includes "not only voting and other forms of electoral activity (e.g., wor king in campaigns, making financial contributions) but also contacting public officials, atten ding protests, and getting involved either formally or informally on local issues" (Brady et al. 1995, p. 272 3). 
German around 1800 who stated that "[is it not true that] the lords experience far more difficulty in maintaining authority over their serfs than they did when the latter were still illiterate? [...] The most uncouth and ignorant peasant will invariably make the best soldier. He can be treated as if he were a machine, and when he is so treated one can rely on him absolutely" (quoted in Lindert 2004a, p. 101). Further reasons for rural elites' resistance towards the development of mass schooling were their reluctance to finance an encompassing educational system by paying higher taxes. Additionally, educated workers could seek better-paid jobs in the cities, threatening the supply of cheap labour, which was a fundamental pillar of the latifundia-system (see Galor et al. 2006). Finally, secondary school visits would keep the young population from working on landowners' fields. ${ }^{16}$

This section claimed that the type of agrarian structures (plantation-style agriculture based on cheap hired labour versus small-plot farming based on family work) left footprints on the educational outcomes of Latin American and Asian countries. The following section provides a brief description of the agrarian structure and landlords' political influence in some selected countries. Furthermore, it presents historical evidence of rural oligarchies' resistance towards educating the masses.

\section{Some descriptive and historical evidence}

The first group of countries plotted in Fig. 3 show very low secondary education attainment levels and only a marginal difference between secondary and tertiary schooling. At the same time, the agriculture of these states was dominated by politically influent latifundistas highly dependent on the uninterrupted supply of cheap labour. Brazil's first republican constitution, for example, existed from 1891 until 1934 and is believed to have largely represented the interests of the agrarian elite. ${ }^{17}$ The constitution abolished free and compulsory education, reversing education legislation and maintaining this situation for more than four decades. Moreover, the first republican constitution delegated the responsibility for educational policies to the states. The only states to enact special decrees for the public financing of primary and secondary education were the three Southern pro-

16 This paper concentrates on landlords' resistance towards secondary (rather than primary) edu cation for several reasons related to the causal mechanisms outlined above. First, it can be assumed that children who are younger than eleven years of age do not constitute an important workforce for landowners, as their potential contribution to farms' productivity is only margi nal. Landlords may therefore have been less reluctant to accept primary school visits. Further more, since especially secondary schooling is believed to qualify workers to take up jobs in the industrial sector, this kind of education constituted a considerable threat to the supply of rural laborers. Finally, cross sectional variance of secondary education is larger than of primary schooling for the period under analysis (most of the countries in the sample exhibit high primary school coverage after 1960).

17 This period of Brazilian history is known as República das Oligarquias (Republic of the Olig archies). The leading politicians of this period came from two major political parties: Partido Republicano Paulista (PRP) and Partido Republicano Mineiro (PRM). Both parties represented the interests of the agrarian elite, especially the coffee producers from Sao Paulo and cattle owners from Minas Gerais. 
vinces. ${ }^{18}$ Throughout Brazilian history, these states were always characterized by a more unimodal distribution of peasant or family farms.

The Brazilian newspaper O Estado de Sao Paulo offers evidence of landlords' political articulation power and the incapability of the Brazilian government to promote secondary education. One editorial in 1919, for example, encourages adults to engage in civic behaviour and send their children to school, since it seems impossible for the government to enact obligatory schooling (O Estado de Sao Paulo, 1919, p. 4). The newspaper dedicated much space to covering the mostly unsuccessful attempts to reform secondary education. ${ }^{19}$ Once enacted, the secondary school reform received a lot of criticism for not being far-reaching. ${ }^{20}$

The traditional Central American landed elite also had a disproportionate effect on the policy making process until very late in the $20^{\text {th }}$ century (see Stone 1990). In Guatemala and El Salvador, landlords retained coercive forms of labour exploitation into the period of coffee expansion. Weeks (1986, p. 115) acknowledges that in the year $19702 \%$ of Salvadorian rural families owned about $65 \%$ of the total cropland. In Guatemala, the land reform enacted by the liberal reformers (Decree 170) strengthened the coffee oligarchy by absorbing indigenous campesinos' land and employing their labour. By labour laws like Decrees 177 or 243, the Guatemalan liberal state relied on different forms of coercive labour control such as debt peonage or vagrancy laws, compelling the indigenous population to work for the state or for plantation owners. Yashar (1997, p. 40) notes that, with the expansion of commercial coffee estates, General Barrios "even obliged local political chiefs to aid landlords in their attempts to draft indigenous workers". A similar picture applies for the two other Central American countries shown in Fig. 3.

In Colombia, the federal government attempted to implement a centralized educational system with obligatory schooling for children aged 6-14 around 1870. Conservatives, representing landed oligarchy interests, formed a massive opposition against the reform, expressing their discontent in several periodicals. Loy (1971, p. 292) notes that after this reform attempt, the "drop in educational quality and in the number of public schools and students caused even the reformers to express disillusionment". Safford (1995) confirms that Colombian landowners exercised strong social and political domination at the local level, resisting the enforcement of any governmental policies perceived as inimical to their interests.

The Peruvian history provides another example for landowners' opposition against schooling expansion. During the early $20^{\text {th }}$ century, landowners from the country's highland fiercely fought the promotion of private indigenous elementary schools. According to Hazen (1978, p. 429), "Indian teachers were imprisoned and intimidated, as were those who would seek education". Schooling buildings were burned and popular instruction was alleged to be synonymous with subversion and anarchy. In their resistance against Indian drive for instruction, landowners from the Altiplano counted with various allies such as prominent politicians or the local religious oligarchy. Prada (1941, p. 80) quotes one Puno priest, who declaimed thus before an Indian group: "God has ordained that you

18 The decrees $13.175,13.390$ and 13.460 were issued between 1918 and 1919.

19 See e.g. O Estado de Sao Paulo 01/17/1925, 01/19/1925, 01/21/1925 or 04/08/1931.

20 See e.g. O Estado de Sao Paulo 04/25/1931 or 04/26/1931. 
should dedicate yourselves to pasturing your flocks and not to learning to read, which only grieves your fathers and mothers".

The second group of Latin American countries shown by Fig. 4 is characterized by the lack of a politically powerful, homogenous rural elite dependent on cheap labour. In Chile, big landowners had no hegemony over the political decision making process and could not be singled out as a particularly repressive class (see Bauer 1995). Moreover, Chile's agrarian reforms under the elected governments of Eduardo Frei Montalva (1964-1970) and Salvador Allende (1970-1973) further weakened the already subordinate landed elite. Mexican landlords started losing their hegemonic power with the revolutionary upheavals of 1910-1917. The Mexican hacienda system was dissolved almost completely by the populist government of Cárdenas between 1934 and 1940. And, although Argentina was characterized by a large holding pattern, the dominant activity was ranching. Landowners, thus, had comparatively low labour requirements. Generally, there was little need for them to act collectively to ensure cheap labour by restricting peasants' political participation in politics. The same applies to Uruguay, where ranching became the main agricultural income source in late $19^{\text {th }}$ century.

Different than the other Central American states reported in Fig. 3, Jamaica and Panama's agriculture was always characterized by the existence of a small-scale sector of family farms. In Panama, bananas were produced on peasant farms, as virtually all rural families owned or occupied a plot. The country never counted with a strong landed oligarchy. In Jamaica, large holdings producing sugarcane, bananas or coffee for the export market coexisted with a broad small-scale sector of family farms cultivating crops for the domestic market. As shown by Fig. 4, all these countries seem to have put greater emphasis on secondary schooling.

Similarly, the smaller, more diffuse and fragmented agrarian Asian producers were in no position to deter state promotion of educational policies and halt the modernization process. The landlord class was almost absent in countries such as Taiwan and South Korea, as most of the large landowners had been expropriated by the beginning of the industrialization in the 1950s. In these and other Asian countries such as Malaysia and the Philippines, landlords historically did not exert as much national economic or political power as the Latin American latifundistas. In India, landowners' political influence has varied considerably from state to state. While the agrarian aristocracy suffered a loss of political power in many states, landlords managed to keep considerable political control in more feudalistic federal units such as Bibar and Bengal, blocking agrarian reforms in those regions. Consequently, educational output varies greatly between Indian states (see Banerjee and Iyer 2005).

\section{Empirical analysis}

In this statistical analysis, the world trade flows dataset from Feenstra el al. (2005) was aggregated into the categories proposed by Leamer (1984) for the period 1960-2000. To check whether powerful landlords influence educational policies as hypothesized, the share of plantation crops over total exports is used as a proxy. It is assumed that the more an economy is dependent on the export of these kinds of crops, the more "plantation- 
style" its agricultural system is and the higher the political power of landlords..$^{21}$ This operationalization is not unproblematic. As mentioned in the previous section, some Central American states grow cash crops such as coffee or bananas on smaller family plots and are therefore erroneously classified as having a plantation-style agrarian structure. However, from the seven Central American countries included in the sample, ${ }^{22}$ merely Panama, Costa Rica and Jamaica present small-scale agriculture based on owner-operated land. Given that these countries also exhibit above-average secondary school attainment, the chosen operationalization only underestimates the expected negative relationship between plantation crops and secondary education.

As an indicator for countries' agrarian structure, the ratio of plantation crops in exports was preferred over measures of land inequality mainly for three reasons. First, crosscountry availability of measures such as the land Gini index is extremely scant. Second, the export of plantation crops better accounts for landowners' demand of a cheap labour force. Finally, land Gini indices may not reflect the true size of landholdings. Countries showing an equal distribution of very large farms exhibit low Gini indices and would erroneously be classified as having family-owned agrarian systems.

The main independent variables of interest are: export of animals, cereals, forestry, minerals, fuels and labour-intensive as well as capital-intensive manufacturing. The first econometric analysis regresses the percentage of the population over 15 years of age with primary, secondary, higher or no education on these variables. The dependent data was compiled in five year intervals by Barro and Lee (2001). ${ }^{23}$

According to the hypotheses, plantation crops are expected to reduce secondary schooling while increasing higher education. As theorized, landlords want to impede the political mobilization of the workforce by blocking the promotion of secondary schooling and, at the same time, guarantee the public financing of universities for their children. The exports of cereals, animals and forestry are not expected to have a statistically significant negative impact on secondary schooling, as cereals are usually grown on smaller plots and do not require a large pool of cheap and coerced labour. Animals, in particular cattle, are also less labour-intensive. Forestry is a more capital-intensive activity that is believed to have positive spill-over effects on several industrial sectors. The export of capital-intensive manufacturing is expected to increase higher education attainment within a country.

Mineral and fuel exports were included to compare the effect of agricultural exports on educational attainment controlling for the effect of other natural resources. The "natural

21 Economically powerful actors do not necessarily have to be political influential. However, the historical evidence from Latin America and Asia tells us that in almost every country with plan tation style, extensive agriculture and a concentrated landownership structure, landlords form a cohesive, resilient and politically influential group. As argued, this might be explained by lower collective actions costs compared to the numerous small family farmers in Asia.

22 See footnote 23.

2324 countries have sufficient data available: Argentina, Brazil, Chile, Colombia, Costa Rica, Dominican Republic, Ecuador, El Salvador, Guatemala, Honduras, Hong Kong, India, Indone sia, Jamaica, Korea Republic, Malaysia, Mexico, Nicaragua, Panama, Peru, Philippines, Singa pore, Thailand, Venezuela. 
resource curse" literature finds that extracting fuels and minerals particularly impacts economic growth negatively. ${ }^{24}$ Agricultural exports, in contrast, are believed to have no impact on growth. Sala-i-Martin and Subramanian (2003, p. 10), for example, note that "oil and minerals give rise to massive rents in a way that food or agricultural resources do not". The authors conclude that while oil and minerals harm economic growth, agrarian exports show no effect. One of the causal mechanisms used by this literature to explain the negative association between oil and economic growth is that countries rich in these resources tend to neglect education (see Gylfason 2001). To the best of my knowledge, this causal mechanism has not been tested in a comparative way. Thus, comparing the possible effects that fuels, minerals and agricultural goods might have on different types of educational categories may bring new insights to this literature.

Three different types of control variables frequently found in the literature are included in the model. ${ }^{25}$ Demographic factors such as the percentage of the population under 15 were significantly correlated with educational spending in previous models. Both the percentage of the population between 6 and 11 and the share of people between 12 and 17 years of age have been included in the model. Data was retrieved from the UN Population Division's website. ${ }^{26}$ While the first variable is expected to be positively correlated with primary and secondary school attainment, the second should increase post-basic education. GDP per capita was taken from the Penn World Table Version 6.1 (Heston et al. 2001) as an economic control variable. Poorer countries are expected to devote the largest share of their educational budget to primary schooling, while richer states tend to spend more on higher education. Finally, the level of democracy is measured by following Londregan and Poole's (1996) suggestion: they subtract Gurr's Polity VI AUTOC score from the DEMOC score. The final measure of democracy ranges from -10 (totally autocratic) to +10 (totally democratic). To avoid data truncation of the dependent variable, one additional educational category has been included as an independent variable in each model. Since the determinants included in the model are believed to affect educational attainment figures only in the medium- or long-term, all independent variables have been lagged one period (five years).

The econometric method suggested by Beck and Katz (see Beck and Katz 1995 or Beck 2001) has rapidly become standard for similar studies in comparative politics. ${ }^{27}$ However, as the authors note, this method may yield incorrect results when the number of time components is less than 10. Given the structure of the pooled data, with only 9 points in time compared to 24 countries, the econometric options were limited. Arrelano and Bond (1991) derived a Generalized Method of Moments estimator using lagged levels of the dependent variable and of other predetermined variables. The remaining, strictly

24 See Sachs and Warner (1995, 2001), Gylfason (2001), Sala i Martin and Subramanian (2003) or Isham et al. (2005).

25 Papers considering all or part of these control variables are Kaufman and Segura Ubiergo (2001), Brown and Hunter (2004), Stasavage (2005) or Avelino et al. (2005).

26 The data is available at: http://esa.un.org/unup/ (April 5th, 2008).

27 The two authors suggest applying OLS estimators with panel corrected standard errors, unit and period fixed effects as well as including the lagged dependent variable when analyzing pooled cross sectional time series data. 
exogenous variables are differenced. Although the Arellano-Bond dynamic panel data estimator is especially suitable for this kind of panel structure, it would severely diminish the number of cases. Thus, the method of choice was the generalized estimation equation (GEE) extension of generalized least-squares estimation (Liang and Zeger 1986). Like the method suggested by Arellano and Bond, this technique is especially useful for datasets with few points in time and relatively more countries. Under such circumstances, it reduces the risk of generating estimators that are affected by autocorrelation and heteroscedasticity. Table 1 reports the final results for four models (each of them using a different educational level as dependent variable).

The main finding to be extracted from the table above is that the export of plantation crops reduces secondary school attainment. The coefficient for this variable is negative and significant, providing evidence for the hypothesis that fewer people living under plantation-style agricultural attend secondary school. Additionally, these kinds of crops increases the number of citizen without any school formation and seem to create a demand for some amount of highly-skilled workers, as it raises the share of people holding a university degree within the population. Other types of agricultural goods such as cereals, animals or forestry as well as all remaining export categories do not show any significant effect on secondary education. It seems likely then that the conditions associated with the cultivation of plantation crops are responsible for the neglect of secondary education in most of Latin America (all other factors equal).

There are other interesting insights yielded from the quantitative analysis. Besides plantation crops, forestry also increases university attendance. Capital and labour-intensive manufacturing seem to further higher education as well, while decreasing the share of the population visiting primary schools. In addition, the export of capital-intensive manufacturing is associated with more people not having any kind of school formation. The export of fuels and minerals spur the number of universities students, although the effect magnitude is weak when compared to the coefficient of the remaining natural resources. Both export categories have no impact on all other educational categories.

The Polity coefficients show the expected sings: The more democratic a country is, the higher the share of people with basic education and the lower the share of university graduates. This finding is intuitive given that the overemphasis on public higher education in developing countries such as Brazil can be seen as a result of policies favouring a small minority of privileged university students coming mainly from upper-middle or upper classes. Also, more democratic countries have fewer citizens lacking any schooling. Note, however, that none of the Polity coefficients are statistically significant. The demographic variables suggest that the younger the population, the higher primary and secondary school attainment. Countries showing a high percentage of people between 12 and 17, in contrast, seem to put less emphasis on primary education. Finally, richer countries tend to exhibit a higher share of citizens holding university degrees.

One potential and important source of bias that remains unaddressed is endogeneity. As proposed by standard international trade theory, not only the export structure influences educational attainment but also the type of human capital found within a country determines its specialization pattern. The five-year lag of all right-hand side variables might have removed some of this bias. In addition, all export categories, as dependent variables, were regressed on the educational levels and no reversed associations proved 
Table 1: Pooled TSCS analysis using educational attainment as dependent variable

\begin{tabular}{|c|c|c|c|c|}
\hline & No education & $\begin{array}{l}\text { Primary } \\
\text { education }\end{array}$ & $\begin{array}{l}\text { Secondary } \\
\text { education }\end{array}$ & Higher education \\
\hline Dependent $_{t} 5$ & $\begin{array}{l}0.910 \\
(0.017)^{* * * *}\end{array}$ & $\begin{array}{l}0.821 \\
(0.040)^{* * * *}\end{array}$ & $\begin{array}{l}1.012 \\
(0.051)^{* * * * *}\end{array}$ & $\begin{array}{c}1.090 \\
(0.023)^{* * * *}\end{array}$ \\
\hline Primary Edu ${ }_{t 5}$ & $\begin{array}{r}0.0004 \\
(0.023)\end{array}$ & & & \\
\hline Secondary $E d u_{15}$ & & $\begin{array}{l}0.106 \\
(0.045)^{* *}\end{array}$ & & $\begin{array}{c}0.033 \\
(0.014)^{* *}\end{array}$ \\
\hline Higher $E d u_{t}$ & & & $\begin{array}{c}0.019 \\
(0.070)\end{array}$ & \\
\hline $\begin{array}{l}\text { Plantation crops } \\
\text { Expo }_{\mathrm{t} 5}\end{array}$ & $\begin{array}{c}1.835 \\
(1.111)^{*}\end{array}$ & $\begin{array}{c}1.383 \\
(1.969)\end{array}$ & $\begin{array}{c}4.095 \\
(1.756)^{* *}\end{array}$ & $\begin{array}{l}1.951 \\
(0.660)^{* * *}\end{array}$ \\
\hline Animal $\operatorname{Expo}_{\mathbf{t} 5}$ & $\begin{array}{c}0.973 \\
(4.341)\end{array}$ & $\begin{array}{c}1.972 \\
(9.245)\end{array}$ & $\begin{array}{l}9.054 \\
(5.507)\end{array}$ & $\begin{array}{c}0.010 \\
(1.580)\end{array}$ \\
\hline Cereal $\operatorname{Expo}_{\mathrm{t} 5}$ & $\begin{array}{c}1.361 \\
(1.770)\end{array}$ & $\begin{array}{c}0.553 \\
(3.924)\end{array}$ & $\begin{array}{c}2.855 \\
(3.459)\end{array}$ & $\begin{array}{l}2.343 \\
(0.814)^{* * *}\end{array}$ \\
\hline Forest $\operatorname{Expo}_{\mathrm{t} 5}$ & $\begin{array}{l}9.906 \\
(3.667)^{* * *}\end{array}$ & $\begin{array}{c}5.268 \\
(4.857)\end{array}$ & $\begin{array}{c}0.765 \\
(4.307)\end{array}$ & $\begin{array}{c}1.365 \\
(1.629)\end{array}$ \\
\hline $\begin{array}{l}\text { Mineral } \\
\text { Export }_{\mathrm{t}}\end{array}$ & $\begin{array}{c}0.004 \\
(0.012)\end{array}$ & $\begin{array}{c}0.017 \\
(0.027)\end{array}$ & $\begin{array}{c}0.001 \\
(0.017)\end{array}$ & $\begin{array}{l}0.019 \\
(0.007)^{* * *}\end{array}$ \\
\hline Fuel Export $_{t 5}$ & $\begin{array}{c}0.009 \\
(0.010)\end{array}$ & $\begin{array}{c}0.023 \\
(0.015)\end{array}$ & $\begin{array}{c}0.007 \\
(0.019)\end{array}$ & $\begin{array}{c}0.015 \\
(0.006)^{* *}\end{array}$ \\
\hline $\begin{array}{l}\text { Labor intensive } \\
\text { Manu }_{\text {t } 5}\end{array}$ & $\begin{array}{c}4.653 \\
(3.278)\end{array}$ & $\begin{array}{c}0.616 \\
(3.364)\end{array}$ & $\begin{array}{c}1.692 \\
(4.885)\end{array}$ & $\begin{array}{l}2.238 \\
(0.763)^{* * *}\end{array}$ \\
\hline $\begin{array}{l}\text { Capital intensive } \\
\text { Manu }_{\text {t } 5}\end{array}$ & $\begin{array}{c}8.105 \\
(4.581)^{*}\end{array}$ & $\begin{array}{l}17.900 \\
(5.866)^{* * *}\end{array}$ & $\begin{array}{c}1.156 \\
(4.185)\end{array}$ & $\begin{array}{l}4.166 \\
(1.085)^{* * * *}\end{array}$ \\
\hline Polity ${ }_{t 5}$ & $\begin{array}{c}0.045 \\
(0.082)\end{array}$ & $\begin{array}{c}0.125 \\
(0.103)\end{array}$ & $\begin{array}{c}0.029 \\
(0.084)\end{array}$ & $\begin{array}{c}0.018 \\
(0.029)\end{array}$ \\
\hline $\begin{array}{l}\text { Real GDP per } \\
\text { capita }_{t 5}\end{array}$ & $\begin{array}{c}0.0001 \\
(0.0001)\end{array}$ & $\begin{array}{c}7.79 e^{6} \\
(0.0001)\end{array}$ & $\begin{array}{c}0.0001 \\
(0.0001)\end{array}$ & $\begin{array}{l}0.0001 \\
(0.00002)^{* * * *}\end{array}$ \\
\hline $\begin{array}{l}\text { Population } \\
611(\%)_{t 5}\end{array}$ & & $\begin{array}{c}0.351 \\
(0.189)^{*}\end{array}$ & $\begin{array}{l}0.441 \\
(0.157)^{* * *}\end{array}$ & $\begin{array}{c}0.026 \\
(0.076)\end{array}$ \\
\hline $\begin{array}{l}\text { Population } \\
1217(\%)_{t 5}\end{array}$ & & $\begin{array}{l}0.822 \\
(0.255)^{* * *}\end{array}$ & $\begin{array}{c}0.137 \\
(0.175)\end{array}$ & $\begin{array}{c}0.064 \\
(0.095)\end{array}$ \\
\hline Constant & $\begin{array}{c}0.408 \\
(1.101)\end{array}$ & $\begin{array}{l}16.274 \\
(3.315)^{* * * *}\end{array}$ & $\begin{array}{c}5.940 \\
(3.395)^{*}\end{array}$ & $\begin{array}{l}2.980 \\
(0.990)^{* * *}\end{array}$ \\
\hline $\mathrm{N}$ & 184 & 184 & 184 & 184 \\
\hline Wald $\chi^{2}$ & 12848.35 & 2996.17 & 10299.46 & 182982.04 \\
\hline Prob $>\mathrm{Chi}^{2}$ & 0.0000 & 0.0000 & 0.0000 & 0.0000 \\
\hline
\end{tabular}

Note: GEE estimation using robust standard errors (shown in parentheses).

${ }^{*} \quad \mathrm{p}<10 \%$; $^{* *} \quad \mathrm{p}<5 \% ;^{* * *} \quad \mathrm{p}<1 \%$; ${ }^{* * *} \quad \mathrm{p}<0.1 \%$

significant. Also, while human capital might play an important role in shaping countries' export structure, many other elements determine what a country will export; physical capital, labour, quality of institutions and government policies, for example (see Haus- 
mann et al. 2005). Other important possible sources of bias were controlled for as well. Dropping one country at a time, for example, did not alter the results substantially, suggesting that the findings are not driven by outliers. Furthermore, a stepwise inclusion of all independent variables indicated that the reported significant coefficients are not sensitive to the inclusion or exclusion of single variables.

Given that the educational attainment of a population evolves only slowly over time, it can be assumed that most of the explanatory power of the export variables comes from their cross-country variation. It might be claimed, therefore, that the significance of the reported coefficients is exaggerated by the large sample size of the panel data. Also, the present article seeks to analyse how longstanding differences in agricultural class power dynamics have shaped the more recent distribution of educational attainment across countries. Explaining medium-run educational changes within a country by mediumrun fluctuation of plantation crops export is not the primary aim of this paper. To more directly test the proposed hypothesis, the next analysis looks only at the cross-sectional variation. The right-hand side variables were averaged over the period 1960-1995, while the educational attainment variables are 1960-2000 averages. Considering the fact that the exports of minerals and fuels seem to affect only higher education attainment (model 4 of Table 1) and that the sample size is very small, these variables were excluded from the first three models of Table 2 below. Coefficients are estimated using simple ordinary least squares and robust standard errors.

The coefficients summarized above show a similar pattern of statistical significance as in the previous analysis. While negatively associated with secondary schooling, the export of plantation crops seems to spur higher education. ${ }^{28}$ Furthermore, this variable contributes considerably to the total explained variance. When it is excluded from the last two columns of Table 2, the models' $\mathrm{R}^{2}$ drops from 0.72 to 0.66 and from 0.48 to 0.32 , respectively. The export of the other agricultural products remains statistically nonsignificant. As reported before, capital-intensive manufacturing increases the share of the population lacking any formal schooling and reduces the amount of people having enjoyed primary education. Minerals and fuels are positively associated with higher education. Also, the cross-sectional analysis provides additional evidence for the hypothesis that democracy is good for broadly-targeted educational policies. While it diminishes the percentage of people without any schooling, it furthers primary education.

Hence, the main findings derived from the pooled time-series cross-sectional framework are corroborated by the usage of alternative estimation techniques emphasising the cross-section variation. Furthermore, the findings are not the spurious results of employing a high number of observations. In addition, the results presented above proved to be resistant to alternative model specifications..$^{29}$ The export of plantation crops remains significantly and negatively associated with secondary education even after introducing the "settler mortality" variable from Acemoglu et al. (2001). Also, the employment of

28 Note, however, that the export of plantation crops is only significant on the $10 \%$ level. This might be a consequence of the many variables and the few cases considered by the analysis.

29 A stepwise inclusion of the independent variables in the four different models showed that the reported statistical significance of the independent variables is not simply a result of multicolli nearity. 
Table 2: Cross sectional analysis using educational attainment as dependent variable

\begin{tabular}{|c|c|c|c|c|}
\hline & No education & $\begin{array}{l}\text { Primary } \\
\text { education }\end{array}$ & $\begin{array}{l}\text { Secondary } \\
\text { education }\end{array}$ & Higher education \\
\hline $\begin{array}{l}\text { Plantation crops } \\
\text { Expo }\end{array}$ & $\begin{array}{c}19.195 \\
(15.083)\end{array}$ & $\begin{array}{c}1.797 \\
(14.608)\end{array}$ & $\begin{array}{l}15.552 \\
(8.279)^{*}\end{array}$ & $\begin{array}{l}13.771 \\
(7.457)^{*}\end{array}$ \\
\hline Animal Expo & $\begin{array}{c}41.235 \\
(98.140)\end{array}$ & $\begin{array}{c}137.244 \\
(154.465)\end{array}$ & $\begin{array}{c}63.726 \\
(100.435)\end{array}$ & $\begin{array}{c}13.632 \\
(54.970)\end{array}$ \\
\hline Cereal Expo & $\begin{array}{c}21.035 \\
(26.573)\end{array}$ & $\begin{array}{c}15.373 \\
(30.843)\end{array}$ & $\begin{array}{c}29.454 \\
(29.950)\end{array}$ & $\begin{array}{c}28.238 \\
(17.912)\end{array}$ \\
\hline Forest $\operatorname{Expo}_{\mathrm{t} 5}$ & $\begin{array}{c}20.694 \\
(64.816)\end{array}$ & $\begin{array}{c}25.499 \\
(45.327)\end{array}$ & $\begin{array}{c}29.726 \\
(37.363)\end{array}$ & $\begin{array}{c}33.920 \\
(31.726)\end{array}$ \\
\hline Mineral Export ${ }_{t 5}$ & & & & $\begin{array}{c}0.199 \\
(0.069)^{* *}\end{array}$ \\
\hline Fuel Export ${ }_{t 5}$ & & & & $\begin{array}{l}0.183 \\
(0.067)^{* *}\end{array}$ \\
\hline $\begin{array}{l}\text { Labor intensive } \\
\text { Manu }_{\mathrm{t} 5}\end{array}$ & $\begin{array}{l}125.139 \\
(66.624)^{*}\end{array}$ & $\begin{array}{c}6.922 \\
(65.210)\end{array}$ & $\begin{array}{c}52.228 \\
(35.671)\end{array}$ & $\begin{array}{c}71.362 \\
(30.394)^{* *}\end{array}$ \\
\hline $\begin{array}{l}\text { Capital intensive } \\
\mathrm{Manu}_{\mathrm{t} 5}\end{array}$ & $\begin{array}{l}186.686 \\
(57.626)^{* * *}\end{array}$ & $\begin{array}{l}153.485 \\
(61.132)^{* *}\end{array}$ & $\begin{array}{c}41.146 \\
(33.171)\end{array}$ & $\begin{array}{c}13.713 \\
(20.104)\end{array}$ \\
\hline Polity ${ }_{t 5}$ & $\begin{array}{c}2.759 \\
(1.076)^{* *}\end{array}$ & $\begin{array}{c}2.539 \\
(0.874)^{* *}\end{array}$ & $\begin{array}{c}0.393 \\
(0.608)\end{array}$ & $\begin{array}{c}0.216 \\
(0.364)\end{array}$ \\
\hline $\begin{array}{l}\text { Real GDP per } \\
\text { capita }_{\mathrm{t} 5}\end{array}$ & $\begin{array}{c}0.002 \\
(0.002)\end{array}$ & $\begin{array}{c}0.002 \\
(0.0013)\end{array}$ & $\begin{array}{l}0.00097 \\
(0.001)\end{array}$ & $\begin{array}{c}0.0006 \\
(0.0006)\end{array}$ \\
\hline $\begin{array}{l}\text { Population } \\
611(\%)_{t 5}\end{array}$ & & $\begin{array}{l}12.592 \\
(8.035)\end{array}$ & $\begin{array}{c}6.133 \\
(5.362)\end{array}$ & $\begin{array}{c}0.787 \\
(2.867)\end{array}$ \\
\hline $\begin{array}{l}\text { Population } \\
1217(\%)_{t 5}\end{array}$ & & $\begin{array}{c}19.660 \\
(16.896)\end{array}$ & $\begin{array}{c}7.969 \\
(10.017)\end{array}$ & $\begin{array}{c}0.522 \\
(5.578)\end{array}$ \\
\hline Constant & $\begin{array}{c}52.358 \\
(13.304)^{* * *}\end{array}$ & $\begin{array}{c}22.344 \\
(108.314)\end{array}$ & $\begin{array}{c}3.753 \\
(58.002)\end{array}$ & $\begin{array}{c}10.471 \\
(36.354)\end{array}$ \\
\hline $\mathrm{N}$ & 23 & 23 & 23 & 23 \\
\hline $\mathrm{R}^{2}$ & 0.535 & 0.676 & 0.718 & 0.482 \\
\hline $\mathrm{F}$ & 2.51 & 7.25 & 7.78 & 3.25 \\
\hline Prob $>\mathrm{Chi}^{2}$ & 0.0635 & 0.0010 & 0.0007 & 0.0355 \\
\hline
\end{tabular}

Note: OLS estimation using robust standard errors (shown in parentheses).

${ }^{*} \quad \mathrm{p}<10 \% ;^{* *} \quad \mathrm{p}<5 \% ;{ }^{* * *} \quad \mathrm{p}<1 \%$; ${ }^{* * * *} \quad \mathrm{p}<0.1 \%$

alternative estimators (quantile regressions) showed that the findings are not driven by single outliers. ${ }^{30}$

Using education attainment figures as the dependent variable, it is difficult to distinguish the causal mechanism behind the negative association between secondary education and plantation crops. Both the poor public provision of educational resources (as a direct result of landlords' political power) and factors related to individuals' incentives and capabilities to invest in education could be driving this relationship. To illuminate the proposed channel of big landowners trying to block secondary education in fear of

30 All these results are available upon request. 
Table 3: Pooled TSCS analysis using secondary education spending as dependent variable

\begin{tabular}{|c|c|}
\hline & $\begin{array}{l}\text { Public expenditure per secondary student } \\
\text { (as\% of per capita GDP) }\end{array}$ \\
\hline Secondary Expenditure $_{t 5}$ & $\begin{array}{c}0.651 \\
(0.098)^{* * * *}\end{array}$ \\
\hline Plantation Crops $_{\mathrm{t} 5}$ & $\begin{array}{c}5.181 \\
(2.750)^{*}\end{array}$ \\
\hline Animals $_{t 5}$ & $\begin{array}{c}22.036 \\
(13.388)\end{array}$ \\
\hline Forest $_{t 5}$ & $\begin{array}{c}3.368 \\
(15.217)\end{array}$ \\
\hline Cereals $_{t 5}$ & $\begin{array}{c}7.713 \\
(6.733)\end{array}$ \\
\hline Minerals $_{t 5}$ & $\begin{array}{c}0.061 \\
(0.035)^{*}\end{array}$ \\
\hline Fuels $_{t 5}$ & $\begin{array}{l}0.105 \\
(0.026)^{* * * *}\end{array}$ \\
\hline Labor Intensive $\mathrm{Manu}_{\mathrm{t} 5}$ & $\begin{array}{c}4.446 \\
(5.398)\end{array}$ \\
\hline Capital Intensive $\mathrm{Manu}_{\mathrm{t} 5}$ & $\begin{array}{c}5.727 \\
(5.171)\end{array}$ \\
\hline GDP per capita $_{\mathrm{t} 5}$ & $\begin{array}{c}0.0001 \\
(0.0002)\end{array}$ \\
\hline PolitylI $_{t} 5$ & $\begin{array}{l}0.334 \\
(0.126)^{* * *}\end{array}$ \\
\hline Pop12 $17_{t 5}$ & $\begin{array}{c}0.136 \\
(0.467)\end{array}$ \\
\hline Pop6 $11_{\mathrm{t} 5}$ & $\begin{array}{c}0.288 \\
(0.351)\end{array}$ \\
\hline cons & $\begin{array}{c}4.804 \\
(6.472)\end{array}$ \\
\hline $\mathrm{N}$ & 54 \\
\hline Wald $\mathrm{Chi}^{2}$ & 50616.45 \\
\hline Prob $>\mathrm{Chi}^{2}$ & 0.0000 \\
\hline
\end{tabular}

worker's mobilization, UNESCO's educational expenditure data were used as the dependent variable. ${ }^{31}$ This way, governments' concerns with providing extensive secondary schooling is better captured.

Again, the chosen econometrical technique was the generalized estimation equation (GEE) extension of generalized least-squares estimation. To maximize data availability, the expenditure data has also been grouped into 5 year periods. All independent variables are the same as in the previous analysis. The dependent variable is public educational

31 Data were retrieved from the World Development Indicators 2003. 
expenditure per secondary student as percentage of per capita GDP. ${ }^{32}$ The sample includes 17 countries $^{33}$ and the period covered is 1980 to 2000. Again, independent variables have been lagged one period ( 5 years) and the lagged dependent variable was included in the model.

As observed using attainment data, only plantation crops significantly affect educational spending, while all other agricultural categories show no significant impact. Indeed, the governments of countries dominated by plantation-style agriculture spend less on secondary students. Thus, it seems that plantation owners were not interested in states' provision of mass education. Three control variables turn out significant when using educational spending figures. The export of minerals and fuels significantly reduces the amount governments spend on secondary pupils. Therefore, as the "natural resource curse" literature advocates, oil and gas may affect growth through a "neglect of secondary education channel" (see Gylfason 2001). The second interesting finding to be drawn from the control variables is that the more democratic a country, the greater its emphasis on secondary education. All other control variables remain non-significant.

\section{Conclusions}

This paper argued that the persisting difference between Latin American and Asian educational attainment and spending figures may be the legacy of different agricultural production systems in both regions. Within plantation-style agriculture, the persistence of a politically powerful agrarian elite led governments to neglect secondary schooling. In the eyes of big landlords, a more educated population would threaten the supply of cheap labour, an essential pillar of the latifundia-system. Additionally, more educated and, therefore, more politically mobilized citizen would challenge landed aristocracy's monopoly over the political decision making process. Since landlords' source of income was narrow and not easily transferable, political "stakes" were high and any reform that would undermine their political dominance was energetically fought. With only the narrow political support base of a few well-organized landlords, many Latin American governments inhibited mass education for a long period. Concurrently, big landholders advocated university education for their children as well as the supply of a limited amount of high-skilled labour needed in agriculture.

Historical evidence supports the proposed argumentation. Examples of powerful landowners opposing the expansion of education in countries such as Brazil, Colombia or Peru explicitly reflect agrarian elites' negative attitude towards educating the masses. Results of a pooled time-series cross-sectional as well as a purely cross-sectional regression analysis corroborate the paper's main claim. Exports of plantation crops, as proxy

32 This operationalization would be problematic in case public secondary education would be bia sed towards higher income classes (e.g. children of the landowning class). It can be said, howe ver, that in most of the analyzed countries rich parents send their children to private schools.

33 The 17 countries for which data was available are: Argentina, Chile, Colombia, Dominican Republic, Ecuador, El Salvador, Honduras, Korea Republic, Mexico, Nicaragua, Panama, Peru, Venezuela, India, Philippines, Singapore, Venezuela. 
for the political strength of the agrarian elite, reduce secondary educational attainment as well as governments' investments in secondary school students. In addition, plantation crops seem to further higher education relative to secondary schooling. Other agricultural products such as cereals, animals or forestry showed no impact on the different types of educational categories.

These findings indicate that current educational and political inequalities, especially in Latin America, may partly be a historical product of landlords' influence on schooling. The empirical results suggest that specialization in few plantation crops can create a development path with harmful consequences for social equality. Contrary to previous findings, certain types of agricultural structures seem to indirectly harm growth by limiting secondary education attainment. This paper also suggests that the opening up of markets may have even sharpened educational and political inequalities by raising the price of the most abundant factors of production (land) and conferring more economic and political power to landlords. ${ }^{34}$

Opportunities for future research are plentiful and necessary to highlight how different agrarian structures may have conditioned educational policies. Different channels through which agrarian systems might affect educational outputs should be further tested. In particular, the role individual incentives to invest in education plays under plantationstyle or family-owned agriculture seems worthy of further exploration. Also, it appears meaningful to highlight the rural-urban relations when explaining educational outputs from a historical perspective. In particular, varying degrees of landlords' self-interest in the industrialization process across countries might be a key factor explaining the development of broadly-targeted educational policies.

\section{References}

Abente, Diego. 1995. A Party System in Transition: The Case of Paraguay. In Building Democratic Institutions: Party Systems in Latin America, eds. Scott Mainwaring and Timothy R. Scully, 298 320. Stanford, CA: Stanford University Press.

Acemoglu, Daron and James A. Robinson. 2006a. Economic Backwardness in Political Perspec tive. American Political Science Review 100: 115131.

Acemoglu, Daron and James A. Robinson. 2006b. Persistence of Power, Elites and Institutions. NBER Working Paper Series No. 12108. Cambridge, MA: NBER

Acemoglu, Daron and James A. Robinson. 2000. Political Losers as a Barrier to Economic Deve lopment. American Economic Review Papers and Proceedings 90: 126130.

Acemoglu, Daron, Simon Johnson and James A. Robinson. 2001. The Colonial Origins of Com parative Development: An Empirical Investigation. The American Economic Review 91: 13691401.

Arellano, Manuel and Stephen Bond. 1991. Some Tests of Specification for Panel Data: Monte Carlo Evidence and an Application to Employment Equations. Review of Economic Studies 58(2): 277297.

34 Coatsworth (1984), for example, shows how an expansion of opportunities of agricultural exports in Mexico led to a systematic expropriation of Indian lands during the government of General Porfirio Díaz at the beginning of the 20th century. 
Avelino, George, David S. Brown and Wendy Hunter. 2005. The Effects of Capital Mobility, Trade Openness, and Democracy on Social Spending in Latin America, 1980 1999. American Jour nal of Political Science 49(3): 625641.

Baland, Jean Marie and James A. Robinson. 2006. Land and Power: Theory and Evidence from Chile. NBER Working Paper Series No. 12517. Cambridge, MA: NBER.

Banerjee, Abhijit and Lakshmi Iyer. 2005. History, Insitutions, and Economic Performance: The Legacy of Colonial Land Tenure Systems in India. The American Economic Review 95: 11901213.

Barraclough, S. 1973. Agrarian Structure in Latin America. Lexington, MA: D.C. Heath and Co.

Barro, Robert J. und Jong Wha Lee. 2001. International data on educational attainment updates and implications. Oxford Economic Papers 3: 541563.

Bates, Robert H. 1981. Markets and States in Tropical Africa: The Political Basis of Agricultural Policies. Berkeley: University of California Press.

Bauer, Arnold J. 1995. Landlord and Campesino in the Chilean Road to Democracy. In Agrarian Structure \& Political Power. Landlord \& Peasant in the Making of Latin America, eds. Eve lyne Huber and Frank Safford, 39 66. Pittsburgh: University of Pittsburgh Press.

Beck, Nathaniel and Jonathan Katz. 1995. What to do (and not to do) with time series cross section data. American Political Science Review 89: 634647.

Beck, Nathaniel. 2001. Time Series Cross Section Data: What have we learned in the past few years. Annual Review of Political Science 4: 271293.

Binswanger, Hans P. and Mark R. Rosenzweig. 1986. Behavioural and Material Determinants of Production Relations in Agriculture. The Journal of Development Studies 22 (3): 503539.

Boix, Carles. 2003. Democracy and Redistribution. Cambridge, UK: Cambridge University Press.

Bourguignon, François and Thiery Verdier. 2000. Oligarchy, democracy, inequality and growth. Journal of Development Economics 62: 285. 313.

Bowles, Samuel. 1978. Capitalist Development and Educational Structure. World Development 6: 78396.

Brady, Henry E., Sidney Verba and Key L. Schlozman. 1995. Beyond SES: a resource model of political participation. American Political Science Review 89: 27194.

Brown, David S. and Wendy Hunter. 2004. Democracy and Human Capital Formation. Education Spending in Latin America, 1980 1997. Comparative Political Studies 37: 842864.

Bueno de Mesquita, Bruce and Alastair Smith. 2009. Political Survival and Endogenous Institutio nal Change. Comparative Political Studies 42: 167197.

Cleary, Mark and Peter Eaton. 1996. Land Tenure and Rural Development in South East Asia. New York: Oxford University Press.

Coatsworth, John H. 1984. Growth Against Development: The Economic Impact of Railroads in Porfirian Mexico. DeKalb, IL: Northern Illinois University Press.

Cornelius, Wayne A. 1977. Leaders, Followers, and Official Patrons in Urban Mexico. In Friends, Followers, and Factions: A Reader in Political Clientelism, eds. Steffen W. Schmidt, James C. Scott, Carl Landé and Laura Guasti, 337 354. Berkeley: University of California Press.

Downs, Anthony. 1957. An Economic Theory of Democracy. New York: Harper \& Row.

Duncan, K. and I. Rutledge (eds). 1977. Land and Labour in Latin America: Essays on the Deve lopment of Agrarian Capitalism in the Nineteenth and Twentieth Centuries. Cambridge, UK: Cambridge University Press.

Engerman, Stanley and Kenneth Sokoloff. 2005a. Colonialism, Inequality, and Long Run Paths of Development. NBER Working Paper Series, No.9259. Cambridge, MA: NBER.

Engerman, Stanley and Kenneth Sokoloff. 2005b. The Evolution of Suffrage Institutions in the New World. The Journal of Economic History 65(4): 891921. 
Engerman, Stanley and Kenneth Sokoloff. 1997. Factor Endowments, Institutions, and Differential Paths of Growth Among New World Economies: A View from Economic Historians of the United States. In How Latin America Fell Behind, ed. Stephen Haber, 260 304. Stanford: Stanford University Press.

Engerman, Stanley, Stephen Haber and Kenneth Sokoloff. 2000. Inequality, Institutions, and Diffe rential Paths of Growth Among New World Economies. In Institutions, Contracts, and Orga nization, ed. Claude Menard, 108 135. Cheltenham: E. Elgar.

Erickson, Lennart and Dietrich Vollrath. 2004. Dimensions of Land Inequality and Economic Development. IMF Working Paper WP/04/158. Washington D.C.: IMF.

Feenstra, Robert C, Robert E. Lipsey, Haiyan Deng, Alison C. Ma, and Hengyong Mo. 2005. World Trade Flows: 1962 2000. NBER Working Paper Series No. 11040. Cambridge, MA: NBER.

Frankema, Ewout. 2006. The Colonial Origins of Inequality: Exploring the Causes and Conse quences of Land Distribution. Research Momorandum GD 81. Groningen: University of Groningen.

Frieden, Jeffry. 1991. Debt, Development and Democracy. Princeton, NJ: Princeton University Press.

Galor, Oded, Omer Moav and Dietrich Vollrath. 2006. Inequality in Land Ownership, the Emer gence of Human Capital Promoting Institutions, and the Great Divergence. Mimeo.

Grindle, Merilee S. 1977. Bureaucrats, Politicians, and Peasants in Mexico: A Case Study in Public Policy. Berkeley: University of California Press.

Gylfason, Thorvaldur. 2001. Natural resources, education, and economic development. European Economic Review 45: 847859.

Hagopian, Frances. 1996. Traditional Politics and Regime Change in Brazil. Cambridge, UK: Cambridge University Press.

Handelman, Howard. 1980. Introduction. In The Politics of Agrarian Change in Asia and Latin America, ed. Howard Handelman, 2 15. Bloomington: Indiana University Press.

Hartlyn, Jonathan. 1998. The Struggle for Democratic Politics in the Dominican Republic. Chapel Hill: University of North Carolina Press.

Hausmann, Ricardo, Jason Hwang and Dani Rodrik. 2005. What You Export Matters. NBER Wor king Paper Series, No. 11905. Cambridge, MA: NBER.

Hayami, Yujiro and Vernon W. Ruttan. 1985. Agricultural Development. An International Perspec tive. London: The Johns Hopkins University Press.

Hazen, Dan. 1978. The Politics of Schooling in the Nonliterate Third World: The Case of Highland Peru. History of Education Quarterly 18(4): 419443.

Heston, Alan, Robert Summers and Bettina Aten. 2001. "Penn World Table Version 6.1". Center for International Comparisons at the University of Pennsylvania (CICUP).

Huber, Evelyne and Frank Safford (eds.). 1995. Agrarian Structure \& Political Power. Landlord \& Peasant in the Making of Latin America. Pittsburgh: University of Pittsburgh Press.

Isham, Jonathan, Lant Pritchett, Michael Woolcock and Gwen Busby. 2005. The Varieties of Resource Experience: How Natural Resource Export Structures Affect the Political Economy of Economic Growth. The World Bank Economic Review 19(2): 14174.

Kaufman, Robert and Alex Segura Ubiergo. 2001. Globalization, Domestic Politics, and Social Spending in Latin America. World Politics 53: 553587.

Krishna, Anirudh. 2002. Enhancing Political Participation in Democracies. Comparative Political Studies 35(4): 437460.

Kuenzi, Michelle T. 2006. Nonformal Education, Political Participation, and Democracy: Findings from Senegal. Political Behavior 28(1): 131.

Leamer, Edward E. 1984. Sources of International Comparative Advantage. Cambridge, MA: MIT Press.

Liang, Kung Yee and Scott L. Zeger. 1986. Longitudinal Data Analysis Using Generalized Linear Models. Biometrika 73(1): 1322. 
Lindert, Peter. 2004a. Growing Public. Social Spending and Economic Growth Since the Eigh teenth Century. Cambridge: Cambridge University Press, vol. I.

Lindert, Peter. 2004b. Growing Public. Social Spending and Economic Growth Since the Eigh teenth Century. Cambridge: Cambridge University Press, vol. II.

Londregan, John B. and Keith T. Poole. 1996. Does High Income Promote Democracy. World Politics 49(2): 130.

Loy, Jane M. 1971. Primary Education during the Columbian Federation: The School Reform of 1870. Hispanic American History Review 51: 275294.

Moore, Barrington. 1966. Social Origins of Dictatorship and Democracy. Boston: Beacon Press.

Nuñez, Javier. 2005. Signed with an X: Methodology and Data Sources for Analyzing the Evolution of Literacy in Latin America and the Caribbean, 1900 1950. Latin American Research Review 40(2): 117136.

O Estado de Sao Paulo. 1925. O Papel das Escolas. 11/13/1925, p. 4.

O Estado de Sao Paulo. 1919."Instruccao. 02/08/1919, p. 4.

Olson, Mancur. 1965. The Logic of Collective Action: Public Goods and the Theory of Groups. Cambridge, MA: Harvard University Press.

Powell, John Duncan. 1977. Peasant Society and Clientelist Politics. In Friends, Followers, and Factions: A Reader in Political Clientelism, ed. Steffen W. Schmidt, James C. Scott, Carl Landé and Laura Guasti, 147 161. Berkeley: University of California Press.

Prada, Manuel González. 1941. Prosa Menuda. Buenos Aires: Imán.

Sachs, Jeffrey and Andrew Warner. 2001. The curse of natural resources. European Economic Review 45: 827838.

Sachs, Jeffrey and Andrew Warner. 1995. Natural Resource Abundance and Economic Growth. NBER Working Paper Series, No. 5398. Cambridge, MA: NBER.

Safford, Frank. 1995. Agrarian Systems and the State: The Case of Colombia. In Agrarian Structure \& Political Power. Landlord \& Peasant in the Making of Latin America, eds. Evelyne Huber and Frank Safford, 111 150. Pittsburgh: University of Pittsburgh Press.

Sala i Martin, Xavier and Arvind Subramanian. 2003. Addressing the Natural Resource Curse: An Illustration from Nigeria. NBER Working Paper Series, No. 9804. Cambridge, MA: NBER.

Schmidt, Steffen W. 1977. The Transformation of Clientelism in Rural Colombia. In: Friends, Fol lowers, and Factions: A Reader in Political Clientelism, eds. Steffen W. Schmidt, James C. Scott, Carl Landé and Laura Guasti, 305 323. Berkeley: University of California Press.

Smith, Peter H. 1979. Labyrinths of Power: Political Recruitment in Twentieth Century Mexico. Princeton: Princeton University Press.

Stasavage, David. 2005. Democracy and Education Spending in Africa. American Journal of Poli tical Science 49(2): 343358.

Stokes, Susan C. 1995. Cultures in Conflict: Social Movements and the State in Peru. Berkeley: University of California Press.

Stone, Samuel. 1990. The heritage of the conquistadors: ruling classes in Central America from the Conquest to the Sandinistas. Lincoln: University of Nebraska Press.

Vanhanen, Tatu. 1990. The Process of Democratization: A Comparative Study of 147 States, 1980 88. New York: Taylor \& Francis New York Inc.

Weeks, John. 1986. An Interpretation of Central American Crisis. Latin American Research Review 21(3): 3153.

Yashar, Deborah J. 1997. Demanding Democracy. Stanford: Stanford University Press. 